NORTH

AMERICAN

PRIMARY CARE From the North American

GROUP Primary Care Research Group

Ann Fam Med 2010;8:179-180. doi:10.1370/afm.1101.

\section{Reform, Reform Everywhere and Not a Primary Care Dollar to Drink}

In 1993, nipping at the heels of potential health care reform, Franks, Nutting, and Clancy published a paper in JAMA declaring that, "relatively few dollars... have been invested in primary care research." They go on to state, "an expanded research program examining the organization and process of primary care is essential..."1 My, how things have stayed the same. Health care Reform is in the air again. Hopefully, by the time you read this we have some definite answers about what that looks like. Both HR 3962 Affordable Health Care for America Act (House Health Reform Bill) ${ }^{2}$ and HR 3590 Patient Protection and Affordable Care Act (Senate Health Reform Bill) ${ }^{3}$ have passed their respective governmental branches, and are now in committee to iron out the final version. A side-by side comparison can be found at the Kaiser Family Foundation Web site. ${ }^{4}$ How will these 2 bills and health care reform impact NAPCRG and American primary care researchers?

The current health care reform plans both explicitly state the need for a robust primary care system and workforce. Providing coverage does not equal access, and any reform passed will see strong primary care initiatives. MedPAC has testified on the need for strengthening the primary care workforce. The American Academy of Family Physicians has called for additional funds for Title VII and graduate medical education. However, there is very little discussion on the importance of building a strong scientific basis for primary care. Translational research is much more than simply getting the newest drug to market. Primary care researchers understand just how little we really know about the scientific basis for our work, and NAPCRG has always taken a lead in developing and building the scientific basis for primary care. Unfortunately, there are really no solid provisions in the current health care reform legislation that explicitly identify the need for primary care research or provide resources for it. As usual, primary care is viewed as simply a sum of its parts: hypertension care, diabetes management, antibiotic use, organ system after organ system. Or viewed in relationship to access, community health centers, Health Professional Shortage Areas, and increased workforce. There is no explicit understanding or resource for the need to study and learn the best elements or "organization and process" for primary care. While funding access to primary care for millions more Americans, current plans do not include resources to assure that the primary care provided is the best. We need a well-articulated and promoted statement on the unique qualities of primary care and the necessity for a strong research and scientific basis for primary care.

There are a few tidbits in current reform plans that may keep primary care researchers busy for the next few years. Comparative effectiveness research (CER) will see a large infusion of resources, in the range of $\$ 400-\$ 600$ million per year. Many folks will be able to take advantage of these resources, and hopefully primary care researchers can take a prominent role in CER to help our patients at the point of care. The Institute of Medicine has published its top 100 priority topics for CER, and several of the top 10 relate to primary care, such as the effectiveness of carecoordination programs. ${ }^{5}$ In fact, practice redesign, preparing practices for the medical home, and chronic disease management research will see extensive additional resources. It is unclear how much of this money will be directed to pilot projects run by payors or intermediaries rather than primary care researchers. Hopefully, the Primary Care Extension Model initiative will end up in the final reform bill and this may provide some resources for practice-based research networks (PBRNs) to help practices in their redesignmedical-home efforts. There will be several grant mechanisms to study and implement community prevention, wellness, and behavior research and services. NAPCRG researchers have successfully competed for these funds from HRSA, CDC, and AHRQ. AHRQ has been on the forefront of primary care research and practice transformation, and will continue to lead these efforts. The NIH's Clinical Translational Science Awards will continue to provide an opportunity for primary care researchers to take advantage of resources geared towards translation and community engagement. Many of these programs will see increased funding providing research dollars to more primary care researchers.

Health care reform is just out ahead of us as the United States considers the opportunity to provide basic healthcare to millions of its citizens. Primary care will be a cornerstone to reform. Primary care research will likely continue to struggle and need to feed off the other biomedical sciences to build a strong primary care evidence base. The Research Advocacy Working Group of NAPCRG will be looking at ways to push the primary care research agenda over the coming year. We look forward to working with many of you to 
highlight your excellent research and promote the need for a strong scientific basis for primary care.

Jobn M. Westfall, MD, MPH

Chair of NAPCRG Research Advocacy Working Group

Associate Dean of Rural Health

University of Colorado School of Medicine

\section{References}

1. Franks $P$, Nutting $P A$, Clancy CM. Health care reform, primary care, and the need for research. JAMA. 1993;270(12):1449-1453.

2. HR Rep No 3962 (2009). http://docs.house.gov/rules/health/111_ ahcaa.pdf. Accessed Jan 19, 2010.

3. HR Rep No 3590 (2009). http://democrats.senate.gov/reform/ patient-protection-affordable-care-act-as-passed.pdf. Accessed Jan 19, 2010.

4. Kaiser Family Foundation [web site]. Side-by-side comparison of major health care reform proposals. http://www.kff.org/healthreform/sidebyside.cfm. Accessed Jan 19, 2010.

5. Institute of Medicine of the National Academies. Initial National Priorities for Comparative Effectiveness Research. Washington, DC: IOM; 2009. http://www.iom.edu/. Accessed Jan 19, 2010.

\section{SAFP}

Ann Fam Med 2010;8:180-181. doi:10.1370/afm.1105.

\section{Questions and Answers With AAFP President Lori Heim, MD}

AAFP President Lori Heim, MD, who currently serves as a hospitalist at Scotland Memorial Hospital in Laurinburg, North Carolina, recently sat down with AAFP News Now to discuss what's coming down the health care pike this year.

Q: You travel around the country meeting with AAFP members. What concerns do they have for their practices and their patients in 2010?

A: Family physicians are worried. They are concerned about the viability of their practices, and that's not surprising when looking at the financial status of the nation. Members wonder if health care reform will be passed and how it will affect patient access to physicians. They remember the old days of managed care, and they wonder about continuity of care and a disruption of the personal relationship family physicians have with their patients. They see their patients go "out of network" when they change jobs or when their employers change insurance carriers.

Q: What is your vision for the future of the US health care system?

A: I would like to see a basic set of health care benefits available to all Americans and that includes an increased emphasis on prevention.

I had hoped to see a comprehensive health care reform bill passed, knowing full well that it would not have been perfect. However, in the current legislative mode, we are not likely to see the kind of reform called for by the AAFP's Congress of Delegates. I will spend the remainder of my tenure on the Board helping to improve whatever health care legislation Congress passes. The Academy's priorities are clear, and as AAFP president, I will continue to advocate for improved patient access, better payment for primary care and a stronger primary care workforce.

Q: How can the Academy leverage its influence in Washington to help shape health policy to benefit patients and physicians?

A: One way is to make our voice heard in Washington. We've had a tremendous response from members who have joined our Connect for Reform initiative. We will continue to ask them to explain to lawmakers how proposed legislation will affect family physicians and their patients. Legislators need to hear those stories. The Academy's leadership and staff also have a voice in Washington through discussions with White House staff, senior policymakers within the administration, and in testimony before House and Senate committees.

We have been invited to these venues because the Academy is viewed as an honest broker. Our interest in health care reform stems from our concern about the health of this nation and of our patients.

Our voice also is heard through the coalitions we join. We don't always agree with our partners on every issue, but we identify common goals and then advocate for them. It's been a very effective strategy. Just look at the regulatory changes proposed by CMS _ including higher payments to family physicians - as well as the administration's proposed budget for 2011.

Q: What are other top priorities for the Academy in 2010?

A: The health care bills currently in Congress do not adequately address rising costs. The country needs to shift the delivery of health care away from a volume-based system to a quality-based system that measures patient outcomes. "Meaningful use" criteria for electronic health records (EHRs) are also on the AAFP's radar screen, and we'll decipher CMS directives with the goal of helping members qualify for EHR bonus money.

The Academy will look for additional strategies to advance primary care with partnerships in private industry and through the promotion of the patient-centered medical home. That's how we demonstrate the value of family medicine. Many of these initiatives, like our push for tort reform, need to be tackled at the state level. 